\title{
Canna paniculata as natural host of canna yellow streak virus in Brazil
}

\author{
M. A. V. Alexandre ${ }^{1}$ - L. M. L. Duarte ${ }^{1}$ - A. L. R. Chaves ${ }^{1}$ - A. F. Ramos $^{1}$ • \\ R. Harakava ${ }^{2}$ E. W. Kitajima ${ }^{3}$
}

Received: 23 May 2017 / Accepted: 27 July 2017 /Published online: 10 August 2017

(C) Australasian Plant Pathology Society Inc. 2017

\begin{abstract}
Canna yellow streak virus (CaYSV) was identified on Canna paniculata with foliar mosaic symptoms from Piracicaba municipality (São Paulo state, Brazil) by transmission electron microscopy, biological, serological and molecular assays. Pairwise analyses of nucleotide and amino acid sequences (potyvirus cylindrical inclusion region) with homologous sequences revealed the highest identity ( 88.6 and 97.8\%) with CaYSV. This is the first detection of CaYSV in Brazil.
\end{abstract}

\section{Keywords Potyvirus $\cdot$ Canna lily $\cdot$ Cannaceae}

Cannaceae is of neotropical origin, with native species from the Southern United States to Northern Argentina (Maas-Van de Kamer and Maas 2008). Of the 217 scientific plant names cited by the Plant List (2013), only 12 are accepted as species names. In Brazil, the occurrence of four native Canna species (C. glauca, C. indica, C. paniculata and C. pedunculata) has been reported, all concentrated in the South and Southeast (Souza and Lorenzi 2012).

Few viruses have been reported in canna plants worldwide; these include Canna yellow mottle virus (CaYMV), a badnavirus, cucumber mosaic virus (CMV) and tomato

M. A. V. Alexandre

alexand@biologico.sp.gov.br

1 Laboratório de Fitovirologia Fisiopatológica, Instituto Biológico, Av. Conselheiro Rodrigues Alves, 1252, CEP 04014-900 São Paulo, SP, Brazil

2 Laboratório de Bioquímica Fitopatológica, Biológico, Av. Conselheiro Rodrigues Alves, 1252, CEP 040140-900 São Paulo, SP, Brazil

3 Escola Superior de Agricultura Luiz de Queiróz, USP, CP 09, CEP 13418-900 Piracicaba, SP, Brazil aspermy virus (TAV), cucumovirus, as well as bean yellow mosaic virus (BYMV) and sugarcane mosaic virus (SCMV), both potyviruses (Monger et al. 2007; Marino et al. 2008; Rajakaruna et al. 2014; Tang et al. 2016). Another potyvirus, Canna yellow streak virus (CaYSV), was reported in the United Kingdom in 2007, and other countries (Monger et al. 2007; Rajakaruna et al. 2014; Chauhan et al. 2015). Although the canna lily is commonly found in nature as well as in public and private gardens in Brazil, to date there has been no reported occurrence of viral diseases in these plants. As such, the aim of this study was to identify and characterize virus(es) associated with mosaic symptoms in Canna paniculata (sin. C. brasiliensis, C. denudata, Distemon kunzei, D. miniatus) leaf samples (Fig. 1) from a public garden in the municipality of Piracicaba, São Paulo state.

Elongated flexuous particles were observed by electron microscopy in extracts from negatively stained symptomatic canna plants (Canna Br01). Ultra-thin sections showed the presence of type II lamellar inclusions, according to Edwardson and Christie's (1996) classification, suggesting the sample was infected with a potyvirus.

Indirect ELISA with antisera against BYMV and CMV, and DAS-ELISA with Potyvirus group and banana bunchy top virus (BBTV, Babuvirus) - commercial antisera (AGDIA), exhibited negative results. BBTV was included because it is considered a quarantine pest in Brazil, and $C$. indica may be an alternative host of this virus even though it is closely associated with Musa sp. (Pinili et al. 2013).

A $684 \mathrm{bp}$ fragment corresponding to the potyviral CI region was produced from Canna-Br01 after total RNA extraction with Trizol (Life Technologies Ambion) and RT-PCR using genespecific primers for the cylindrical inclusion region $(\mathrm{CI})$ of the potyvirus (Ha et al. 2008). Forward and reverse sequencing of the amplicon was performed in an automated DNA sequencer, followed by BLAST analysis and alignment with those 


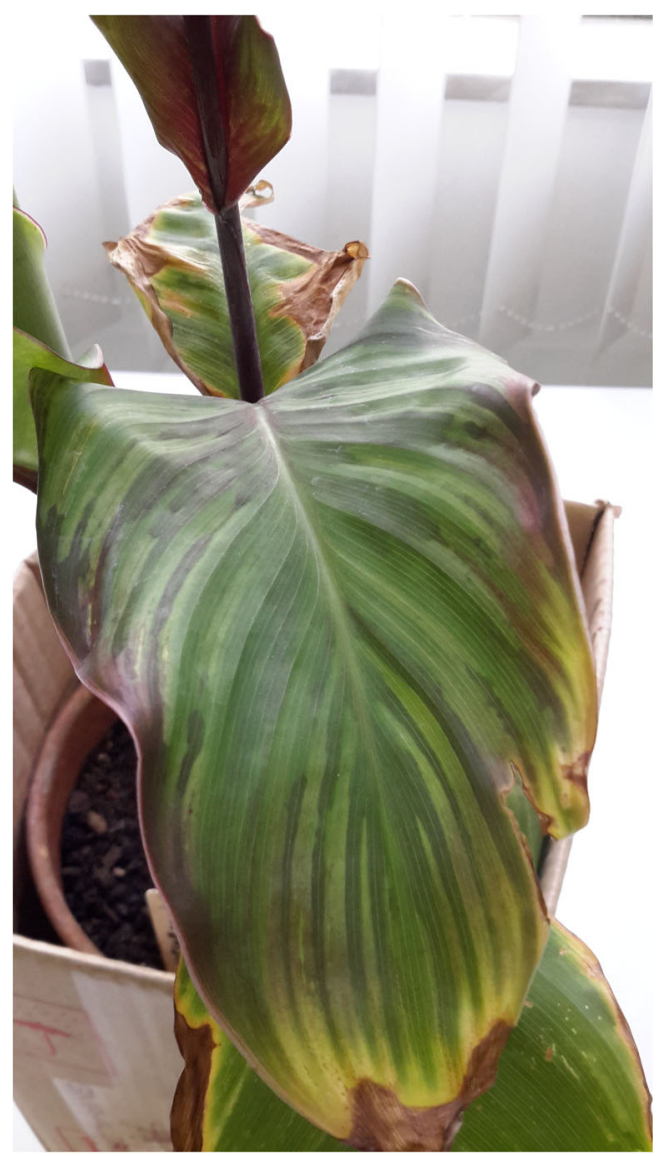

Fig. 1 Canna paniculata with mosaic symptoms along leaf veins

retrieved from Genbank. Maximum likelihood (ML) analysis using PAUP v. $4.0 \mathrm{~b} 10$ for Macintosh was performed after estimation of nucleotide substitution and gamma distribution (Modeltest v.3.06). The homologous sequence of the rymovirus ryegrass mosaic virus (RgMV) (Y09854) was used as outgroup, and bootstrap values were calculated (1000 resamplings). Identity percentage was determined using the PAUP program. BLAST analysis revealed that the Canna-Br01 (GenBank accession number KX897955) potyvirus sequence was $89 \%$ identical to CaYSV from the UK (GQ421689) in genomic RNA positions 3754 to 4433 . Sequence analysis showed an identity percentage ranging between 94.6 and 97.8 at amino acid level (Table 1). Furthermore, the CaYSV-Br01 virus (KX897955) shares $71 \%$ identity with JGMV at the CI amino acid level. Monger et al. (2010) reported 76\% identity for the same genome region with JGMV.

A monophyletic group with $100 \%$ bootstrap support formed by $\mathrm{CaYSV}-\mathrm{Br} 01$ with $\mathrm{CaYSV}$ isolates available in GenBank was observed (Fig. 2). In addition, the group formed by CaYSV isolates, including a Brazilian isolate, shared a common ancestor with JGMV and the cocksfoot streak virus (CSV). Chauhan et al. (2015) showed that CaYSV belongs to the SCMV subgroup and is closely related to JGMV. On the other hand, in our phylogenetic analyses CaYSV and JGMV did not form a monophyletic group with SCMV.
Chauhan et al. (2015) compared the sequence corresponding to the CI of several American isolates of CaYSV (GenBank accession: KM882640-KM882648) and found $100 \%$ identity of nucleotides and amino acids, with the exception of the UK isolate (NC013261), which showed 94\% sequence identity. In our study, CaYSV-BR01 shares more identity with the UK isolate, corroborating biological data.

To evaluate probable infections by a badnavirus, total DNA was isolated (Noris et al. 1994) and two degenerate primers (BadnaFP and BadnaRP) corresponding to the consensus sequences of the Reverse Transcriptase (RT) and RNaseHcoding regions of Badnavirus (Yang et al. 2003) were used. DNA from the Bougainvillea spectabilis chlorotic vein banding virus (BCVBV, Badnavirus) (KF600735) was used as positive control. PCR performed to detect the badnavirus did not amplify any fragment.

Attempts to infect seedlings of Petunia x hybrida, Nicotiana benthamiana, Chenopodium amaranticolor, Catharantus roseus, Phasaelus vulgaris cv. Preto, Carioca, Rajado and Canna sp., obtained from healthy plant seeds, with the virus from Canna-Br01 leaf extract failed. This isolate infected only $20 \%$ of the inoculated canna plants. The results of mechanical transmission attempts in this study were essentially similar to those reported by Rajakaruna et al. (2014),

Table 1 Comparison of identity percentage in nucleotides (NT) and amino acids (AA) of the potyvirus Canna paniculata (Canna-Br01) isolate, corresponding to the partial sequence of the cylindrical inclusion region, with potyvirus sequences retrieved from GenBank

\begin{tabular}{lll}
\hline Potyvirus isolations/accession number & NT & AA \\
\hline Canna yellow streak virus (CaYSV)/GQ421689/NC013261 & $\mathbf{8 8 . 6}$ & $\mathbf{9 7 . 8}$ \\
CaYSV isolate/KM882641 - KM882647 & $\mathbf{8 5 . 7}$ & $\mathbf{9 4 . 6}$ \\
Johnsongrass mosaic virus (JGMV)/Z26920 & 67.1 & 71.0 \\
JGMV/KT289893 & 65.1 & 71.1 \\
Panax virus Y/NC014252 & 58.4 & 49.8 \\
Clover yellow vein virus/AB732962 & 57.2 & 50.7 \\
Pennisetum mosaic virus/JX070156 & 56.9 & 52.9 \\
Moroccan watermelon mosaic virus/EF579955 & 55.5 & 48.4 \\
Sorgum mosaic virus/KM025048 & 55.5 & 48.4 \\
Maize dwarf mosaic virus/JX185302 & 55.4 & 49.5 \\
Potato virus Y/KR046206 & 55.1 & 46.2 \\
Sugarcane mosaic virus/EU091075 & 54.7 & 48.0 \\
Bean yellow mosaic virus/NC003492 & 54.4 & 48.0 \\
Cocksfoot streak virus/NC003742 & 54.2 & 46.2 \\
Turnip mosaic virus/KJ936093 & 53.9 & 51.1 \\
Bidens mottle virus/EU250214 & 53.5 & 48.0 \\
Yam mosaic virus/NC004752 & 53.0 & 43.5 \\
Watermelon mosaic virus/DQ399708 & 52.0 & 44.9 \\
Zucchini yellow mosaic virus/NC003224 & 49.6 & 44.9 \\
\hline
\end{tabular}


ryegrass mosaic virus - Y09854

cocksfoot streak virus - NC003742

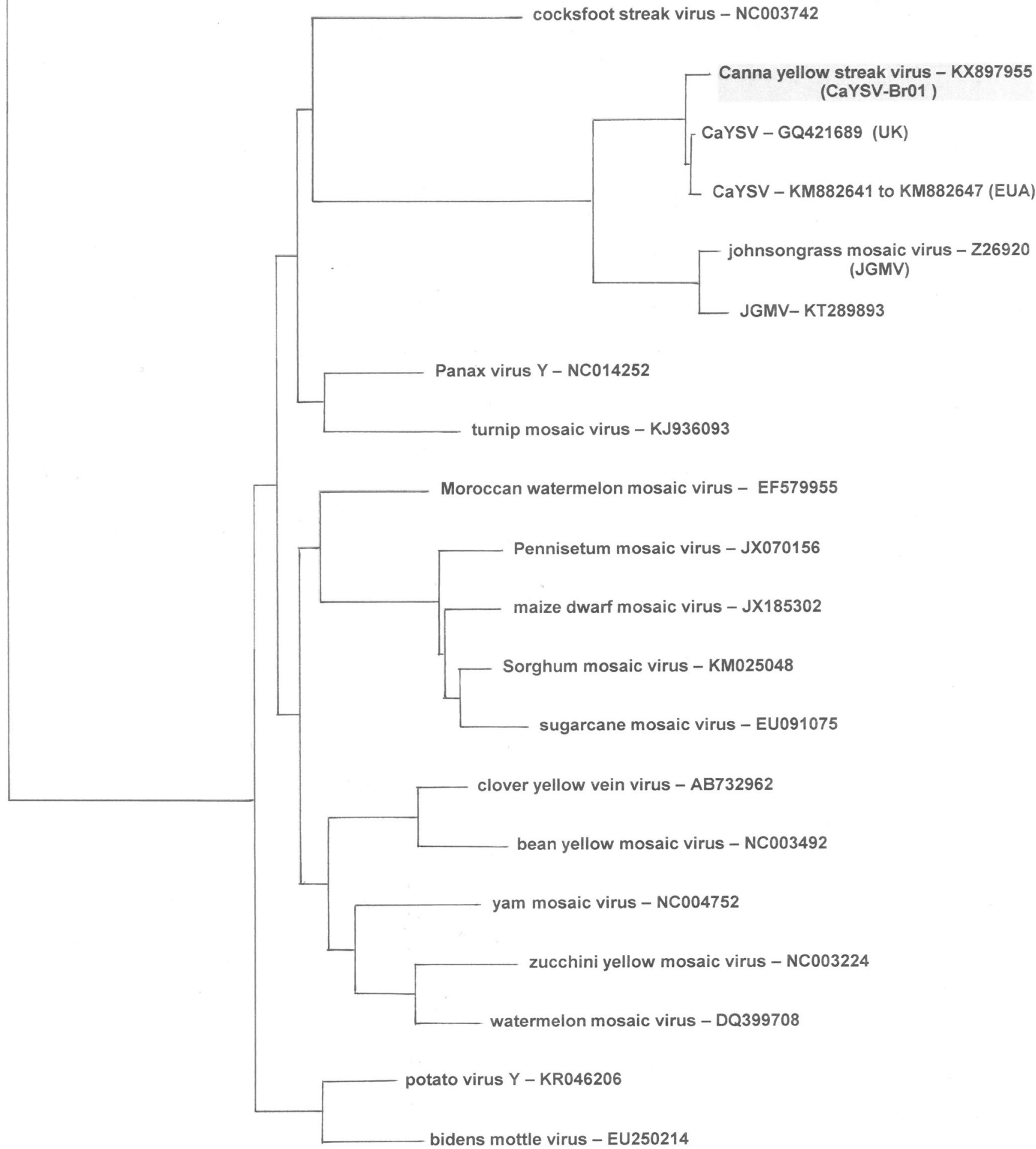

0.1

Fig. 2 A maximum likelihood tree constructed using partial cylindrical inclusion sequences available in GenBank for Potyvirus species, with the ryegrass mosaic virus (Rymovirus) as outgroup. (TrN nucleotide

which state that CaYSV is poorly transmitted by mechanical inoculation using sap from canna leaves. substitution model $+\mathrm{G}, \mathrm{G}=0.4402$ ). Bootstrap values are indicated near the branches. The highlighted sequence corresponds to the Brazilian potyvirus isolate (Canna-Br01)

The occurrence of CaYSV has been reported in various parts of the world (Monger et al. 2010); however, this is the 
first report in Brazil. The increased incidence of viral diseases has been exacerbated since cannas are predominantly propagated via rhizome cuttings and through the frequent international exchange of untested material (Monger et al. 2007). However, C. paniculata is a species whose center of origin is in Brazil, but is also found in Argentina, Paraguay, Peru, Bolivia, Ecuador, Venezuela and Southern Mexico (Maas-van de Kamer and Maas 2008). In contrast to what occurs with C. indica, which was introduced in different countries in Africa, Europe, the Middle East, Asia and Oceania, there are no reports of $C$. paniculata dispersion to other continents. Moreover, CaYSV dispersion may be associated with aphid transmission, since several polyphagous species have been reported associated with $C$. indica and $C$. coccinea species (Blackman and Eastop 2007).

In conclusion, electron microscopy, mechanical transmission, serological tests, RNA extraction and RT-PCR assays indicate that the symptoms observed in Canna from Piracicaba (SP), Brazil, are caused by CaYSV, with no other virus present in this plant.

\section{References}

Blackman RL, Eastop VF (2007) Taxonomic issues. In: Harrington R (ed) Van Emden HF. Aphids as crop pests. CABI Publishing, Wallingford, pp 1-29

Chauhan RP, Rajakaruna P, Verchot J (2015) Complete genome sequence of nine isolates of canna yellow streak reveals its relationship to the sugarcane mosaic virus (SCMV) subgroup of potyviruses. Arch Virol 160:837-844

Edwardson JR, Christie RG (1996) Cylindrical Inclusions. Florida Agricultural Experiment Stations Bulletin n. 894: Gainesville
Ha C, Coombs S, Revill PA, Harding RM, Vu M, Dale JL (2008) Design and application of two novel degenerate primer pairs for the detection and complete genomic characterization of potyviruses. Arch Virol 153:25-36

Maas-Van de Kamer H, Maas PJM (2008) The Cannaceae of the world. Blumea 53:247-318

Marino MT, Ragozzino E, Lochhart BEL, Miglino R, Alioto D (2008) First report of canna yellow mottle virus (CaYMV) in Italy and in the Netherlands. Plant Pathol 57:394

Monger WA, Harju V, Skelton A, Seal SE, Mumford RA (2007) Canna yellow streak virus: a new potyvirus associated with severe symptoms in canna. Arch Virol 152:1527-1530. doi:10.1007/s00705007-0977-2

Monger WA, Adams IP, Glover RH, Barrett B (2010) The complete genome sequence of canna yellow streak virus. Arch Virol 155: $1515-1518$

Noris E, Accotto GP, Luisoni E (1994) Advances in diagnosing tomato yellow leaf curl geminivirus infection. Mol Biotechnol 2:219-226

Pinili MS, Nagashima I, Dizen TO, Natsuaki T (2013) Crosstransmission and new alternative hosts of Banana bunchy top virus. Trop Agric Dev 157:1-7

Souza CS, Lorenzi H (2012) Botânica Sistemática. Guia ilustrado para identificação das famílias de Fanerógamas nativas e exóticas no Brasil, baseado em APG III. 3ed. Nova Odessa, SP, Brazil

Rajakaruna P, Shafiekhani M, Kim T, Payton M, Chauhan R, Verchot J (2014) Production of discernable disease phenotypes in canna by five plant viruses to the genera Potyvirus, Cucumovirus and Badnavirus. Plant Pathol J 63:821-830

Tang W, Xu XH, Sun HD, Li F, Gao R, Yang SK, Lu XB, Li XD (2016) First report of Sugarcane mosaic virus infecting Canna spp. in China. Plant Dis 100(12):2541

The Plant List (2013) Version 1.1. Published on the Internet: http://www. theplantlist.org/. Accessed 01 April, 2017

Yang IC, Hafner GJ, Revill PA, Dale JL, Harding RM (2003) Sequence diversity of South Pacific isolates of Taro bacilliform virus and the development of a PCR-based diagnostic test. Arch Virol 148:19571968 